\title{
多摩川ニヶ領宿河原堰の改築 \\ による堆積土砂の移動 \\ THE SEDIMENT MOVEMENT DUE TO THE RECONSTRUCTION OF NIKARYOU-SYUKUGAWARA WEIR IN TAMA RIVER
}

\author{
福岡捷二 1 海野修司 $2 \cdot$ 成田一郎 $2 \cdot$ 辰野剛志 ${ }^{3} \cdot$ 西本直史 4 \\ Shoji FUKUOKA, Syuji UNNO, Ichirou NARITA, Tsuyoshi TATSUNO and Naoshi NISHIMOTO \\ 1フェロ一会員 工博 Ph. D 広島大学大学院教授 工学研究科社会環境システム専攻 \\ （テ739-8527 広島県東広島市鏡山1-4-1） \\ 2正会員 国土交通省関東地方整備局 京浜河川事務所（２30-0051 横浜市鶴見区鶴見中央2-18-1） \\ 3国土交通省関東地方整備局 京浜河川事務所（テ230-0051 横浜市鶴見区鶴見中央2-18-1） \\ 4 正会員 博(工） 日本建設コンサルタント(株)東京支社（テ105-0004 東京都港区新橋6-17-19）
}

\begin{abstract}
The purpose of this study is to show the effects of the sediment movement due to the weir reconstruction.
Nikaryou-syukugawara weir in Tama River was reconstructed and the weir crest level was dropped about two meters in order to increase the flow sectional area. After the weir completion in 1999, a lot of sediment in the upper reaches of the weir ran off with two floods. It was found through the monitoring data that the flow sectional area in the upper reaches increased due to the sediment run-off. In the lower reaches of the weir, it was found that the harden-silt bed was gradually covered with gravel and that some scour holes were to be shallower. The sediment movement mentioned above is favorable for the river maintenance. A 2D numerical model was applied to the prediction of the sediment movement and it was found that the model is useful.
\end{abstract}

Key Words : Weir reconstruction, Sediment movement, Bed deformation, Monitoring, Numerical model

\section{1. 序論}

取水堰は，河川の水位を調節して，都市用水，かん がい用水及び発電用水等を取水するための施設であり, 多くの河川で設置されている. しかし，取水堰のうち多 くの部分が固定部であるいわゆる固定堰は，堰上流部に おける洪水時の水位上昇や堰下流部における局所洗掘等 を招き，洪水汇濫の原因となることがある．このため河 川管理施設等構造令第 37 条では, 固定堰は流下断面内 に設けないことを原則としている。

多摩川の河口から約 $22.4 \mathrm{~km}$ の地点において昭和 24 年に設置された旧二ヶ領宿河原堰は，幅約 $310 \mathrm{~m}$ のうち 固定部を約 $270 \mathrm{~m}$ も有していた. 旧堰では昭和 49 年 9 月 の台風 16 号出水に㧊いて, 堰下流左岸の取付け護岸の 崩壊を契機とする高水敷侵食が発生して堤防決壊に至り, 民家 19 等が流失・崩壊する災害が発生した. また, 旧 堰の完成後約 50 年も経過し老柯化が進んだことから, 洪水の安全な流下とその維持のため, 建設省（当時）は 平成 6 年度より川崎市と共同で改築事業に着手し, 現在
の二ヶ領宿河原堰（以降, 宿河原堰と記す）は平成 11 年 3 月に竣工した。

旧宿河原堰のような固定堰は，一般に水位の堰上げ だけでなく土砂移動にも影響を与え，堰上流の土砂堆積 や堰下流の河床低下を招く. 旧宿河原堰の固定部敷高は 約 $4 \mathrm{~m}$ もの落差を有するほど高かったため, 堰上流で多 くの土砂が堆積し, 一方, 堰直下流では砂碟の流失によ り固結シルト層（いわゆる土丹層）が広範囲で露出し， さらに, 澪筋部の局所洗掘が進行していた. このような 状況において，堰を全面可動化するとともに堰敷高を約 $2 \mathrm{~m}$ 切下げると, 堰上流の洪水時水位の低下によって堆 積土砂が堰下流へ流出し, 堰上流の河床低下と堰下流の 河床上昇を基本とする河床変化が生じると予想される. しかし, 落差を有する堰周辺では常流, 射流が混在し, さらに，高水敷からの落込み流など複雑な流れが生じる ため, 堰周辺の河床形状がどのように変化するかを予測 するのは容易でない. また, 実際に堰改築（堰敷高の切 下げ）後に河床モニタリングが行狆，その結果につい て議論された例はほとんどない。

堰敷高の切下げという大きなインパクトが周辺河床 
にどのような影響を与えるかは，河道を維持管理する上 で把握すべき重要な事項である．河道断面積の変化だけ ではなく, 護岸等施設の機能維持, 河川利用および河川 環境などに関わる基礎データとして，洗掘位置や洗掘深 の変化, 砂州の移動・変形といった河床変化を把握する ことが重要である.さらに, 平成 13 年 3 月に策定され た「多摩川水系河川整備計画【直轄管理区間編】」では, 河道断面の確保対策として主に 5 堰の堰対策を行うこと としており，これらの堰対策の詳細を検討する上でも， 宿河原堰周辺の河床モニタリングは極めて重要である. このような考え方から京浜河川事務所では, 平成 9 年以 降毎年, 宿河原堰周辺の河床変化を把握するため密な横 断測量（維断方向 $25 \mathrm{~m} \sim 50 \mathrm{~m}$ 毎）を行っている. ちなみ に, 全川の横断測量（繸断方向 $200 \mathrm{~m}$ 毎）は 2 年に 1 回 を基本として行っている.

平成 11 年 3 月の堰竣工後, 平成 11 年 8 月と平成 13 年 9 月に中規模の洪水 (ともに最大流量約 $2,800 \mathrm{~m}^{3} / \mathrm{s}$ ) が発生し, 堰周辺の河床が大きく変化した. 平成 13 年 9 月洪水は, 平均年最大流量 (約 $1,300 \mathrm{~m}^{3} / \mathrm{s}$ ) を超える 流量が約 31 時間も続いた特異な洪水であるため, 短期 間の河床変化ではあるが，宿河原堰の改築による河床一 の影響が現れてきていると考えられる.

そこで, 本論文では, これまで行った宿河原堰周辺 の河床モニタリング結果を整理し，宿河原堰改築（堰敷 高の切下げ）の効果を明らかにする目的で, 堰竣工後の 主に 2 度の洪水による縦横断平面的な河床変化について 検討するとともに, 二次元河床変動計算による河床変化 予測の可能性を検討する.

\section{2. 宿河原墁改築の概要}

\section{（1）堰改築と周辺河道整備の基本的な考え方}

宿河原堰の改築と周辺河道整備にあたり, 委員会を つくり議論をし，以下の考え方に基づいて改築と整備が 行われた ${ }^{1)}$. なお, 河床勾配は堰上流で約 $1 / 500$, 堰下 流で約 $1 / 600$, 河床材料平均粒径は約 $30 \mathrm{~mm}$ である.

(1) 流下能力を確保しさらに河床の安定を図るため堰敷 高を約 $2 \mathrm{~m}$ 切下げ (図-1), 旧堰で約 $4 \mathrm{~m}$ の落差を約 $2 \mathrm{~m}$ にする。

(2) 現況の低水路幅や砂州の状況および堰改筑による水 理量変化を踏まえ, 維持が可能と考えられる低水路 幅 $(200 \mathrm{~m})$ とする.

(3) 堤上流でけ河道弯曲のため洪水流が右岸堤防際に集 中し，また，堰下流では広く露出する固結シルト層 （いわゆる土丹層）の傾きにより流れが常に右岸側 に集中し大きな洗掘が生じていた。 このため, 堰施 設を河道中央に設置し，右岸側に高水敷を造成する ことによって右岸堤防の堤脚を保護するとともに局 所洗掘を解消する (図-2, 図-3).

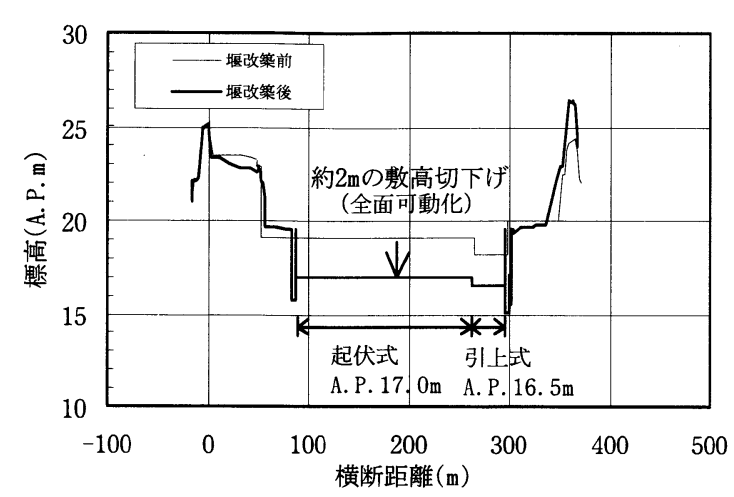

図-1 宿河原堰の横断面図（洪水時）

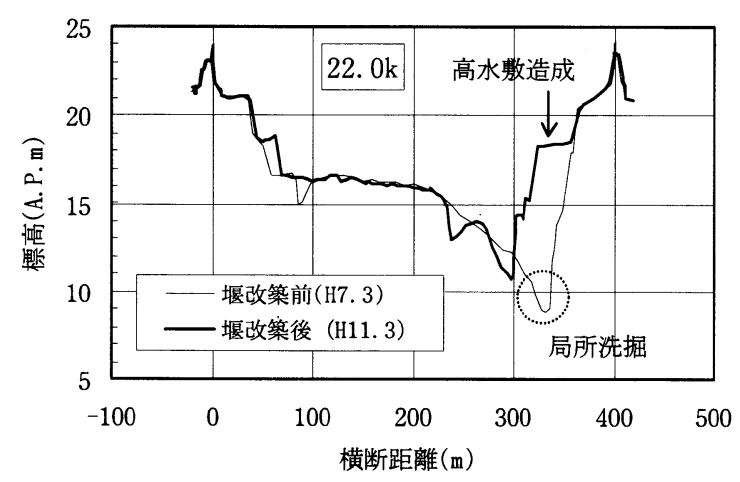

図-2 高水敷造成による局所洗掘の解消

堰改築前 (H4撮影)

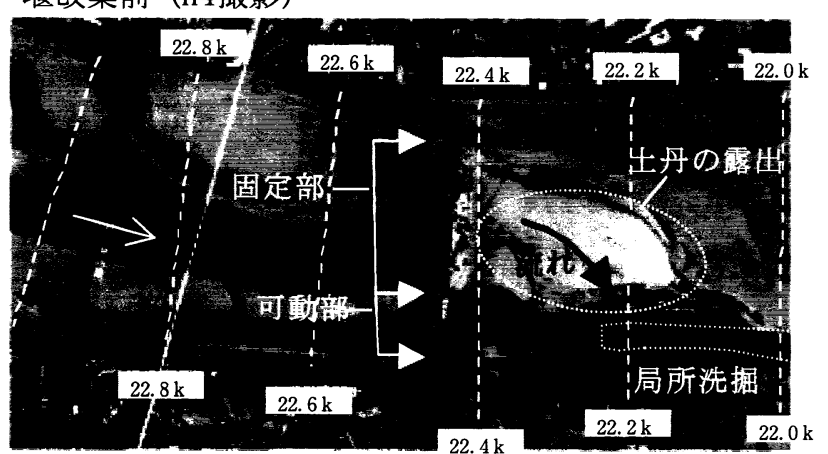

堰改築後 (H11.3撮影)

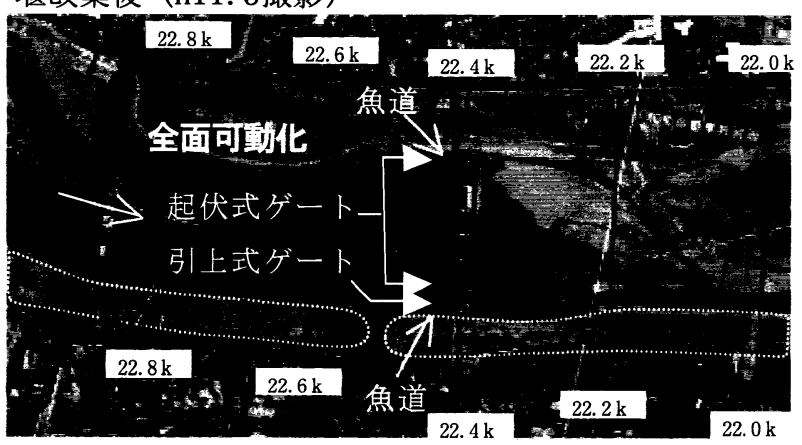

図-3 堰改筑による河道変化

(4) 堰地点での偏流を防止するため堰上流の直線区間を できるだけ設ける。

宿河原堰は，これらの考え方を踏まえ，起伏式ゲート 5 門, 引上式ゲート 1 門の可動堰となった. なお, 魚が のぼりやすい川づくりの一環として, 魚が自由に行き来 できるように左右岸に魚道（右岸: アイスハーバー式と 


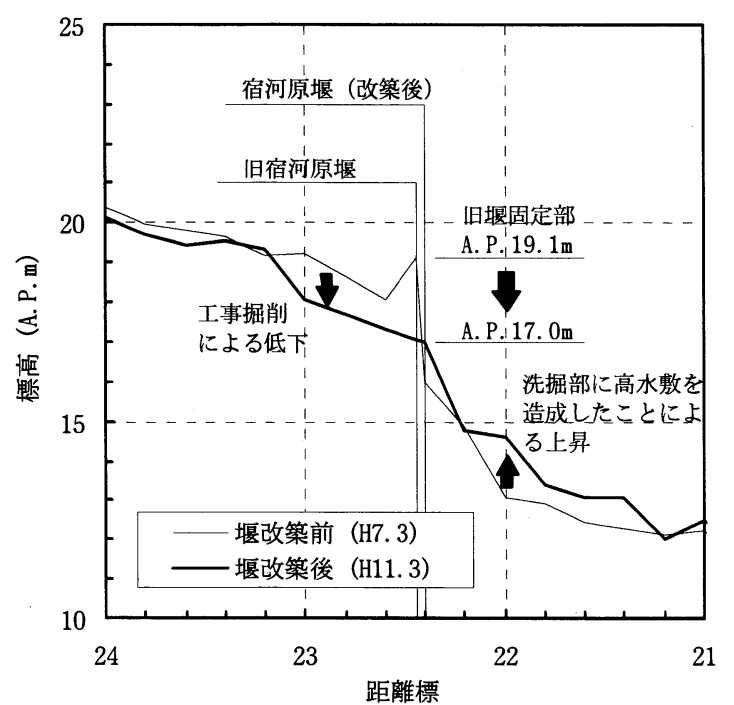

図-4 堰改築による低水路平均河床高の変化

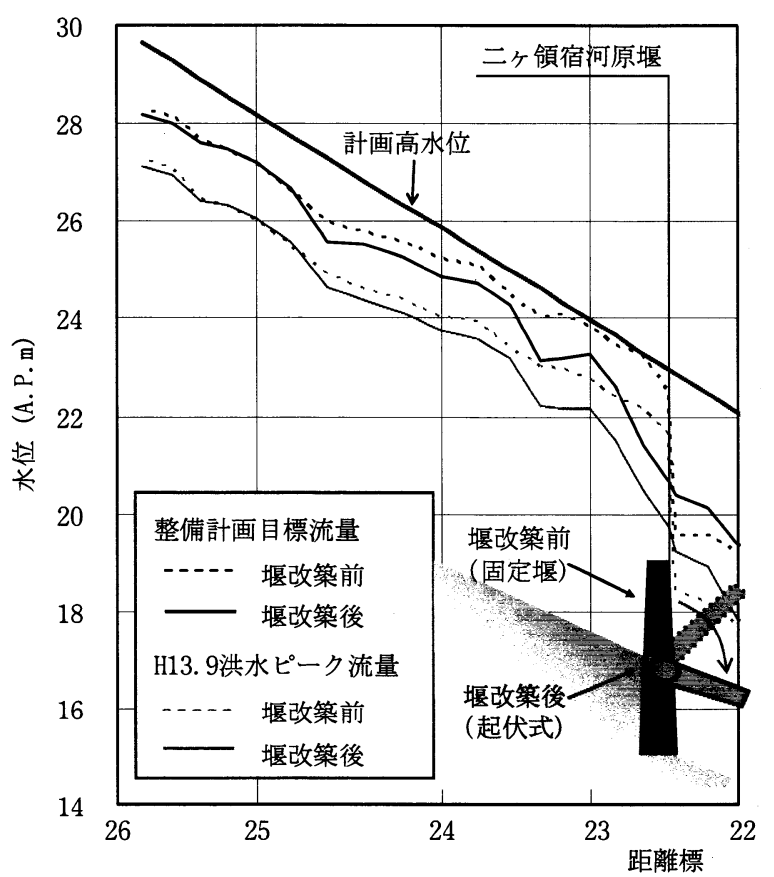

図-5 堰改筑による洪水位の低减効果

と緩勾配水路式，左岸 : 緩勾配水路式）も設けられた。 堰改築工事の結果, 低水路平均河床高は図-4に示す ように大きく変化した. 堰敷高の変化だけでなく周辺河 床も変化しているのは，主にこの工事による. すなわち， 堰上流では砂州を掘削した（高水敷造成等に用いた）た め河床は低下し, 堰下流では高水敷造成により洗掘部が なくなったことで河床が上昇した（図-2参照).

\section{（2）堰改築による洪水位の低減効果}

堰改築による洪水位の低減効果をみるため, 堰改築 前後における同一流量時の計算水位を比較した（図-5). 計算対象流量は, 平成 13 年 9 月洪水のピーク流量 $2,862 \mathrm{~m}^{3} / \mathrm{s}$ と整備計画目標流量 $4,500 \mathrm{~m}^{3} / \mathrm{s}$ (戦後最大規 模の洪水; S49.9 洪水) である. 河道条件として, 堰改 築前河道に平成 7 年 3 月の横断測量成果を用い, 堰改築

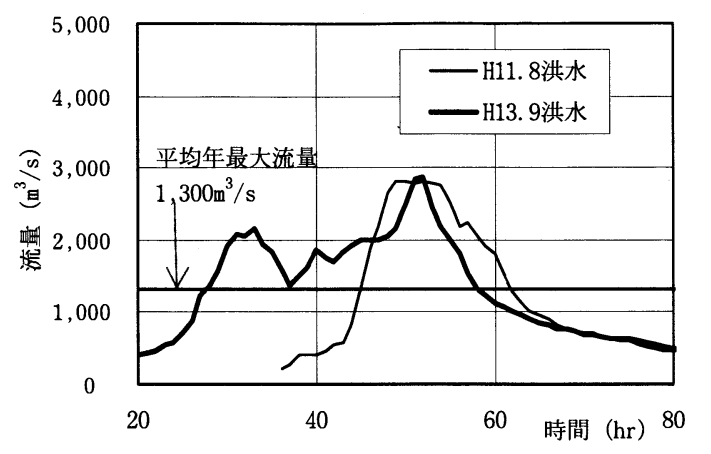

図-6 洪水流量ハイドログラフ

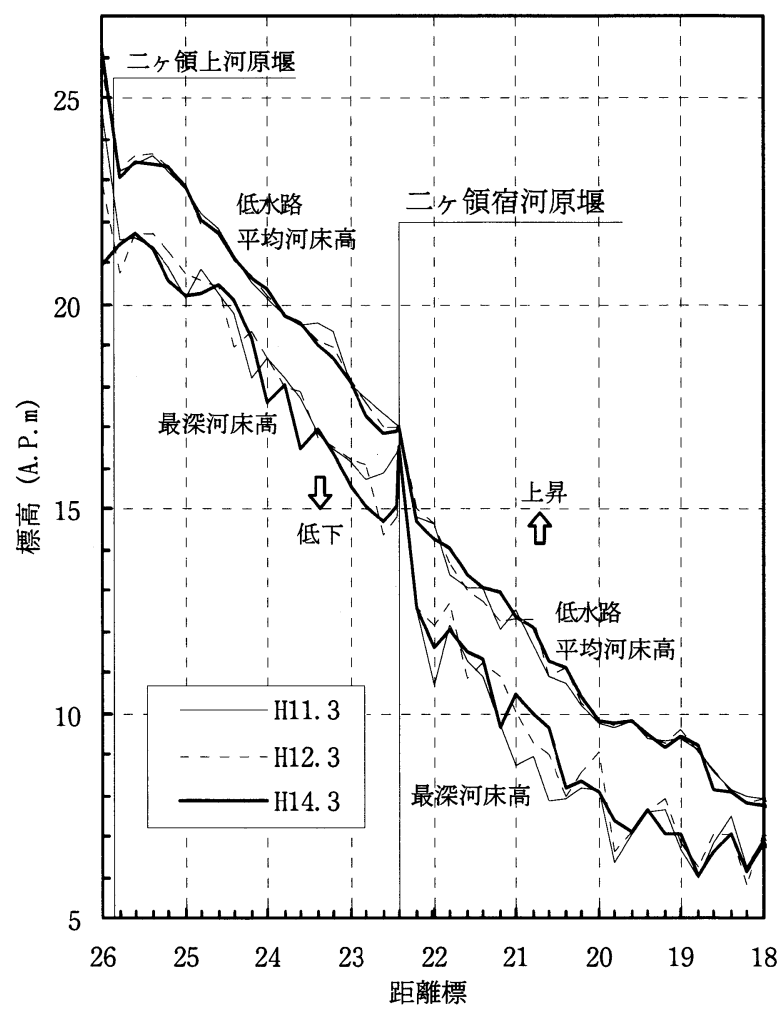

図-7 堰改築後の河床縦断形状の変化

後河道に平成 11 年 3 月の横断測量成果を用いた. 計算 モデルは，一般に流下能力算定に用いられる準 2 次元不 等流計算モデルである.

図-5より堰直上流で約 $2 \mathrm{~m}$ もの洪水位の低減効果があ り，その低减効果は $25 \mathrm{k}$ 地点近くまでの区間で顕著に現 れている.このように，堰改築によって堰上流の洪水疎 通能力が大きく改善されたことがわかる，なお，堰直下 流の水位が堰改築後に少し上昇しているが，これは堰下 流の右岸高水敷造成に起因するものであり，この結果， 堰周辺の水位縦断形は滑らかとなっている.

\section{3. 堰改築による堆積土砂の移動}

\section{（1）河床縦横断形状の変化}

堰竣工後の定期横断測量（縦断方向 $200 \mathrm{~m}$ 毎）は，平 成 11 年 3 月, 12 年 3 月, 14 年 3 月に行われており，こ 


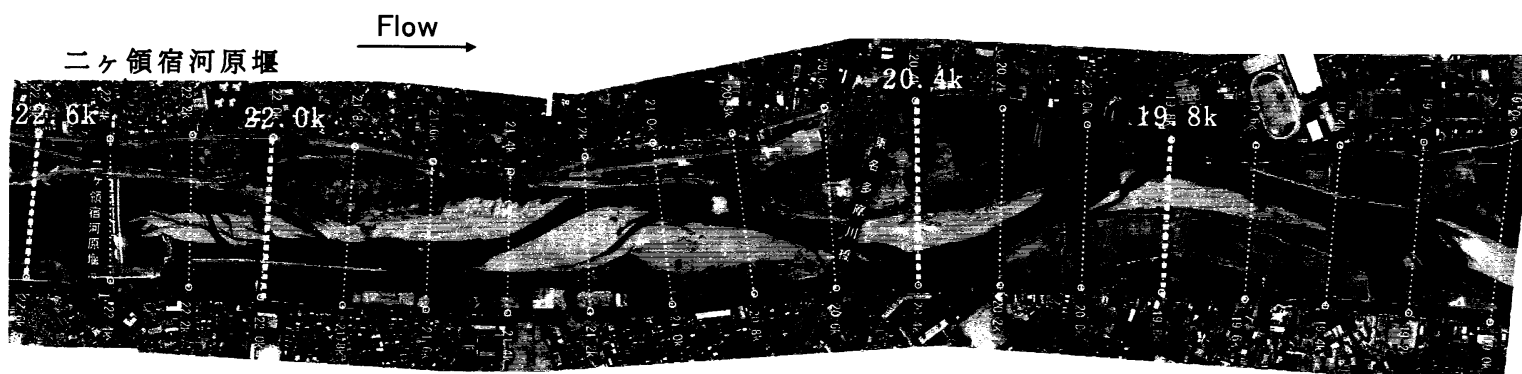

図-8 堰下流の横断測線位置（H13.9 洪水後撮影）
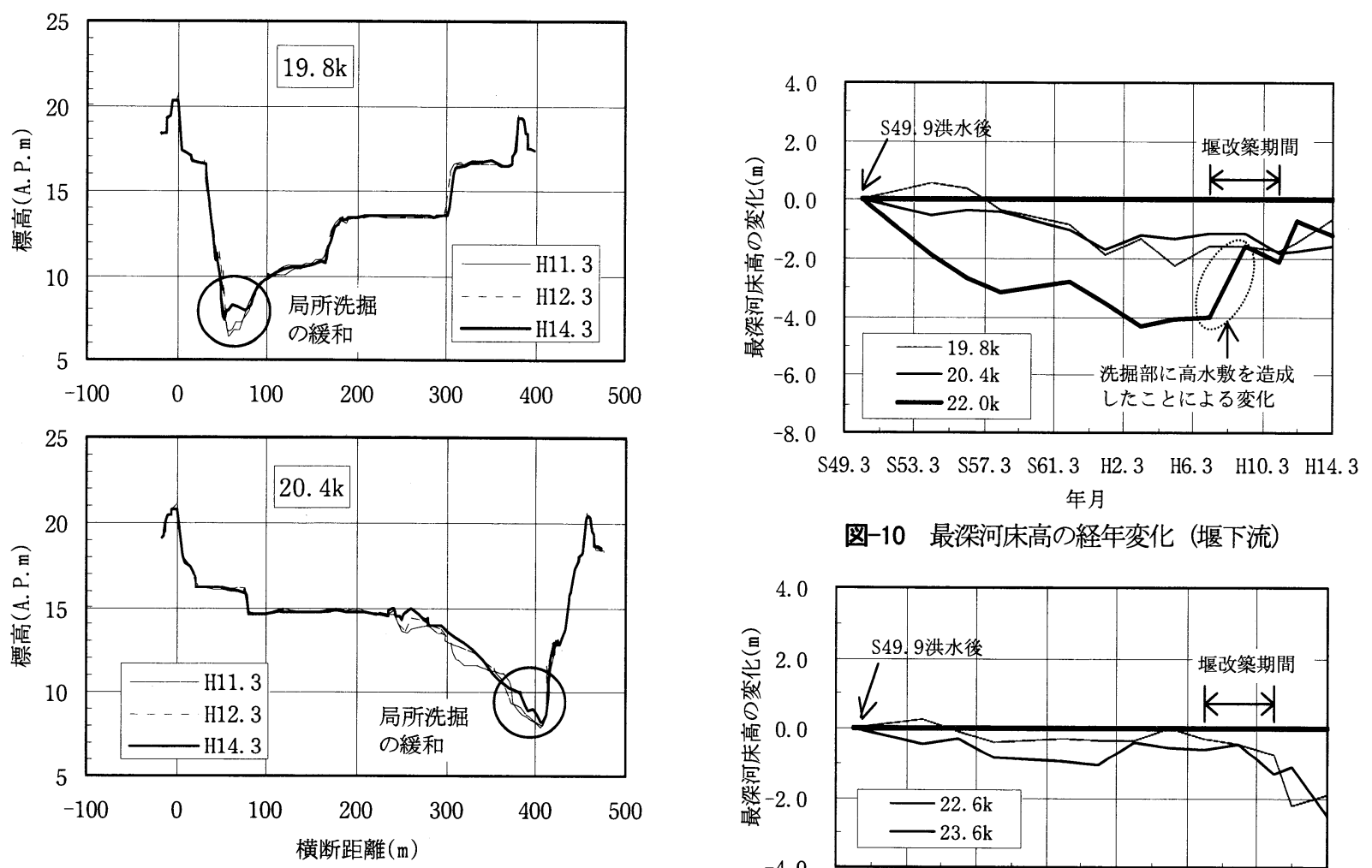

図-9 堰下流の横断形状の変化

の間，平成 11 年 8 .月と 13 年 9 .月に中規模の洪水（概ね 5 年に 1 回の規模）が発生している（図-6).堰竣工後 の堰周辺において，平均粒径約 $30 \mathrm{~mm}$ がほぼ全断面で移 動し始める流量は $300 \mathrm{~m}^{3} / \mathrm{s}$ 程度である. 平成 11 年 3 月 から 14 年 3 月の間で, 上記洪水以外に $300 \mathrm{~m}^{3} / \mathrm{s}$ 以上の 日流量が発生したのは 3 日程度であるため, ここで示す 河床変化はほぼ上記 2 洪水によるものであるといえる. なお，これ以降では 14 年 10 月に約 $2,400 \mathrm{~m}^{3} / \mathrm{s}$ 規模の洪 水があり, 河床変化はさらに進んでいると考えられる.

図-7は，堰竣工後の低水路平均河床高および最深河 床高の変化を縦断的に示している. 平均河床高は, 堰上 流で低下，堰下流で上昇し，その縦断形が滑らかになる 方向に変化している. 最深河床高も平均河床高と同様に 変化し，概ね $19.8 \mathrm{k} \sim 24.0 \mathrm{k}$ の区間で有意な変化が生じ ている.この区間の河床変動土量は，堰上流でー59千 $\mathrm{m}^{3}$, 堰下流で +72 千 $\mathrm{m}^{3}$ であり, 堰上流から流出した土 砂のほとんどが堰下流に堆積したと考えられる.

水衝部が固定化されている $19.8 \mathrm{k}$ と 20.4k 地点（図8) における横断形状の変化は, 図-9に示すとおりであ

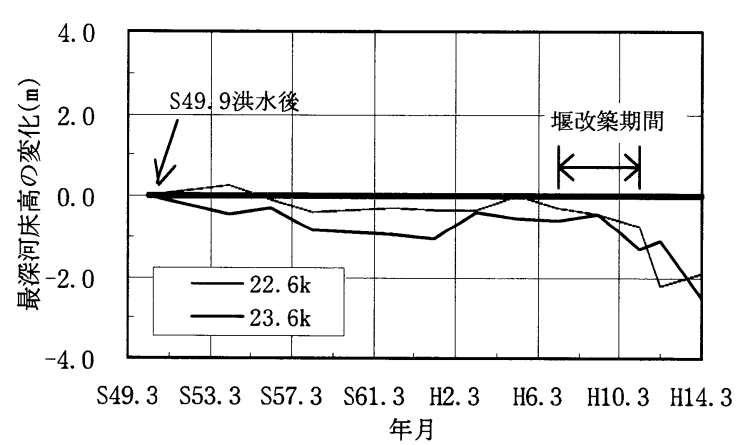

図-11＼cjkstart最深河床高の経年変化（堰上流）

り, 洗掘部が埋め戻されるように河床が上昇している. これらの地点の最深河床高は, 図-10 に示すように昭和 49 年 9 月洪水以降, 低下傾向であったが, 堰改築後に 上昇に転じている. 今後もさらにこの傾向の注視と確認 が必要であるが, このような河床上昇は水衝部の護岸等 施設の機能維持に大きく寄与するため, 維持管理上好ま しいものであるといえる. なお，図-10 には $22.0 \mathrm{k}$ 地点

（図-8 参照）の最深河床高変化も示してある.この地 点における昭和 49 年 9 月洪水以降の最深河床の低下傾 向は，堰下流で広く露出した土丹層の傾きにより流れが 常に右岸側に集中したことによる. 堰改築に伴う高水敷 造成によって洗掘部を埋め戻した後は, 最深河床の低下 傾向はなくなり上昇に転じたようである.

一方, 堰直上流の $22.6 \mathrm{k}$ 地点とその $1 \mathrm{~km}$ 上流の $23.6 \mathrm{k}$ 地点における最深河床高の経年変化は, 図-11 に示すと おりである，最深河床高はともに，堰改築前まではほぼ 安定していたが, 堰改築後には約 $2 \mathrm{~m}$ の堰敷高の切下げ と同程度に低下している。 

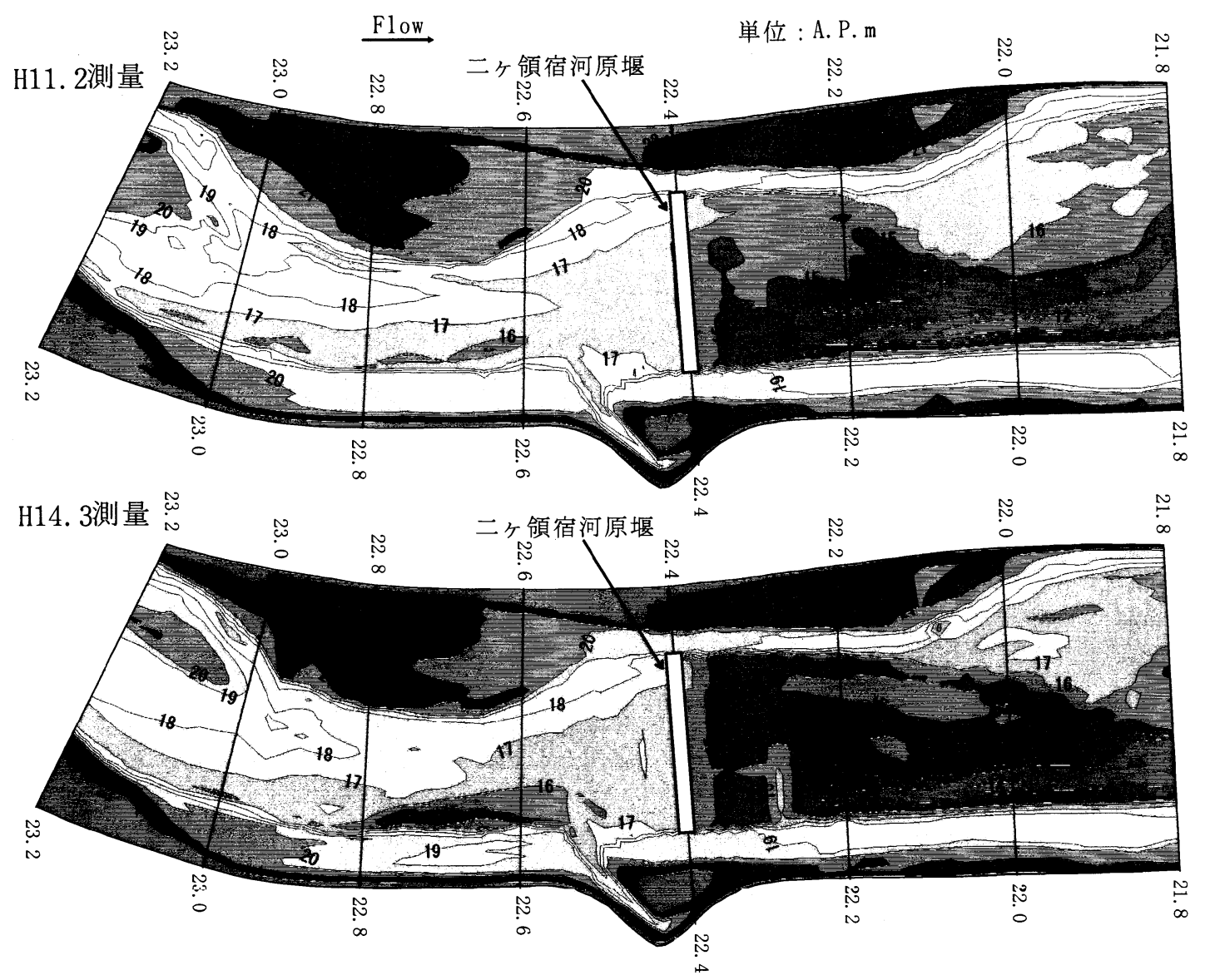

\section{（2）堰周辺の河床高コンター}

図-12 は，平成 11 年 2 月（堰䇋工後）と平成 14 年 3 月の測量成果に基づく河床高コンターである.また, 図-13 はこの間の河床高変化をコンターで表している. これらの図から, 堰上流について以下のことがわかる.

- 堰直上流の河道弯曲のため流水が集中する右岸側 の河床低下が顕著となっている．これは堰敷高の 切下げによる堆積土砂の流出の結果であり, 流下 能力上のネック部の河道断面増大として好ましい.

- $22.6 \mathrm{k} \sim 23.0 \mathrm{k}$ 左岸側の固定砂州が侵食され, 低水 路幅が広くなる傾向にある.これは当初から予想 された治水上好ましい河道断面の拡大傾向である.

- 堆積土砂の流出に伴い $23.2 \mathrm{k}$ 左岸側の砂州が下流 に移動している.

また，堰下流について以下のことがわかる．

- 堰上流の堆積土砂流出の結果, その一部が堰直下 流に堆積し，それまで広く露出していた土丹を砂 礫で覆い始めた（図-8 参照)。このことは, 砂礫河 床を基本とする生態系の再生に大きく寄与するも のと期待され, 今後, 河川環境の観点からも継続 的に注視する必要があるといえる.

- 堰下流の左岸側砂州が侵食され始めた。これは, 堰改築により堰下流の流れが以前よりも均等化さ れたために生じたと考えられる.

- 以上の河床変化から, 堰下流の低水路横断形は, 平滑化される傾向にある.
図-12 堰周辺の河床高コンター

\section{（3）河床変化予測の可能性}

堰敷高の切下げは，周辺河床に大きな影響を及ぼす ため，これを事前に予測できればその影響への適切な 対処が可能となる．そこで，二次元河床変動計算によ る河床変化予測の可能性を調べるため, 上記(2)で示し た河床変化を対象とする再現計算を行った。

二次元河床変動計算モデルは, 浅水流モデルを用い て流れを解き，掃流砂による河床変化ならびに河床材 料変化を求めるモデルである ${ }^{2)}$. なお, 堰地点の落差 のため射流が生じる箇所では護床工が設置されている ため, この箇所を固定床として扱うことによって河床 擾乱の伝播方向に起因寸る解の振動等の問題を回避し ている，具体には，固定床とした箇所で河床低下が生 じないように, 上流側から順次, 流砂量を修正した。

計算対象区間は $21.4 \mathrm{k} \sim 24.4 \mathrm{k}$ で，綐断方向の格子幅 を $25 \sim 40 \mathrm{~m}$ とし, 横断方向に低水路を 15 分割, 高水敷 を 7 分割する格子幅とした. 河床条件として, $24.0 \mathrm{k}$ 地点の河床材料（H13.12 採取）を 13 分割して与えた.

図-14 は, 堰竣工後河床（H11.2）を初期河床として, H11. 8 洪水と H13.9 洪水（平均粒径がほぼ全断面で移 動し始める流量 $300 \mathrm{~m}^{3} / \mathrm{s}$ 以上を対象）を与えて得られ た河床高変化の計算値コンターである. 実測值（図一 13）と比較すると計算結果は, 堰周辺の洗掘, 堆積の 傾向を概ね表している. ただし，以下に示す点につい 


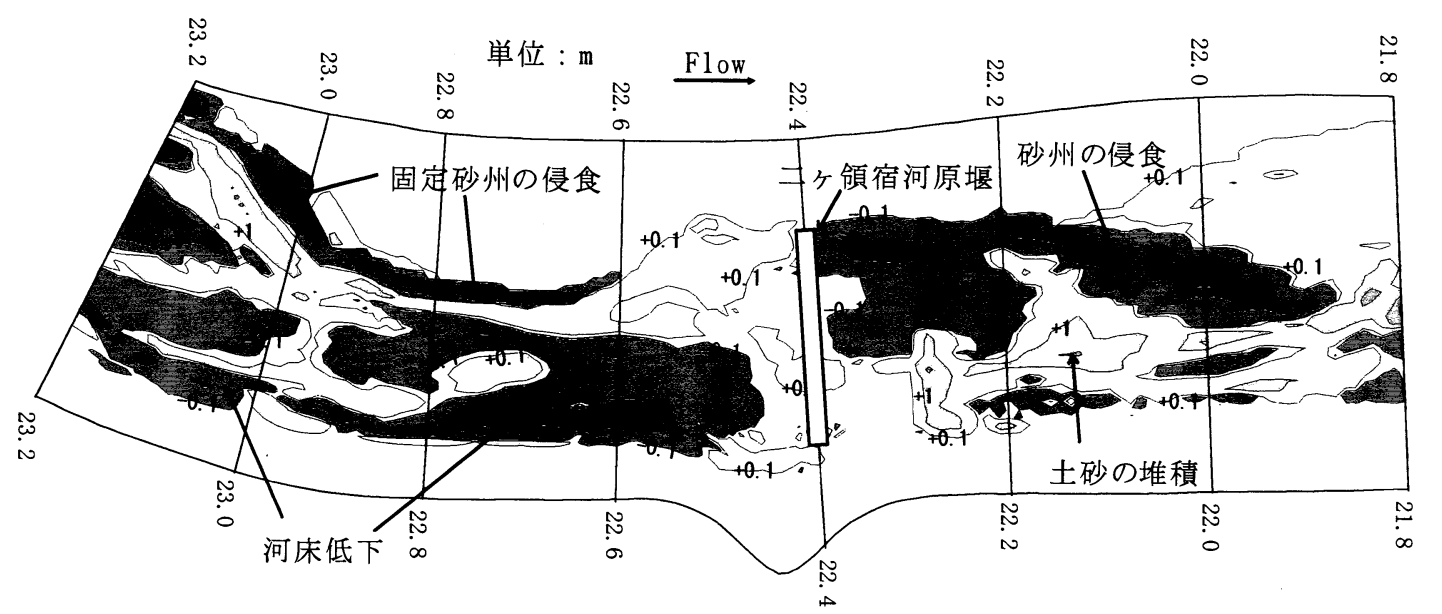

図-13 河床高変化のコンター図 $(\mathrm{H} 11.2 \sim H 14.3$ の変化 $)$

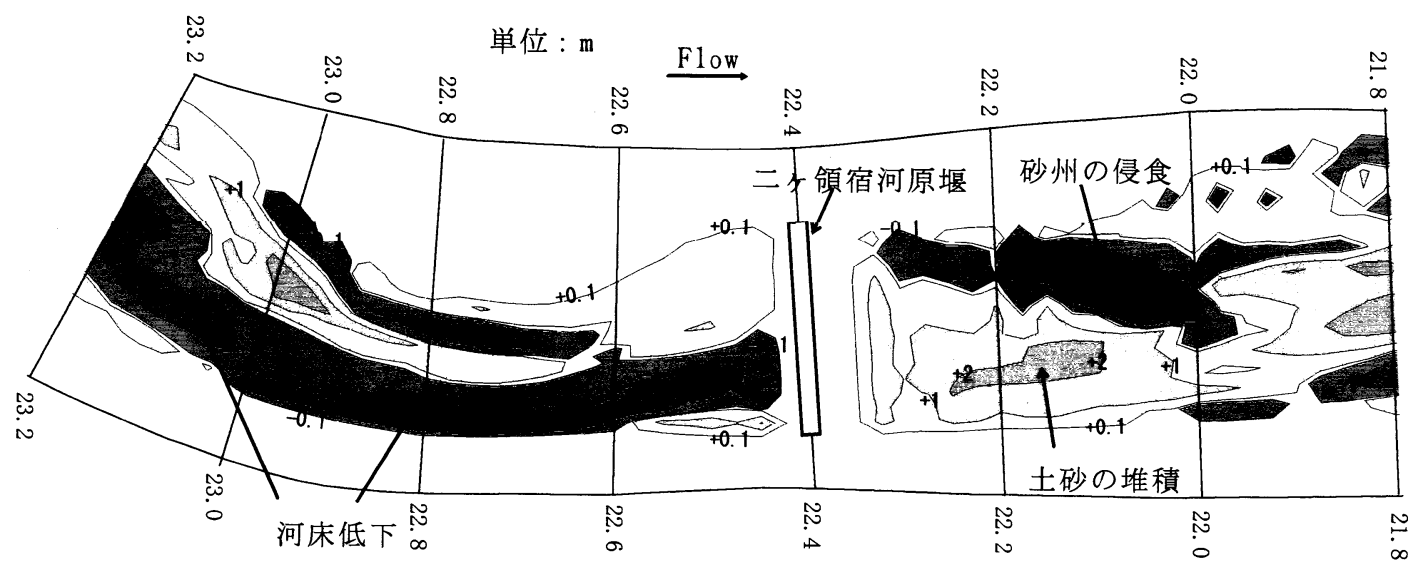

て，計算精度向上の改善余地が残されている.

・堰上流左岸の固定砂州の侵食を考慮すること

・土丹層の存在を考慮すること（堰下流の砂州侵食が 土丹により抑制されていることが考えられる）

堰上流の $24.0 \mathrm{k}$ 地点までの河床変動量の計算値は, -66 千 $\mathrm{m}^{3}$ であり, 実測值の-59 千 $\mathrm{m}^{3}$ と同程度である. 以上から, 二次元河床変動計算は, 河床変化の予測手 法として期待できよう。

\section{4. 結論}

本論文では, 宿河原堰改筑（堰敷高の切下げ）の効 果を明らかにする目的で, 堰竣工後の 2 度の洪水による 縦横断平面的な河床変化について検討した結果を述べた. 堰改築による河床一の影響範囲は堰上下流ともに $2 \mathrm{~km}$ 程 度であり，その中で得られた主な結果を以下に示す。

（1）堰改築後, 堰下流水衝部の洗掘简所が埋め戻される 傾向にある. これは, 護岸等施設の機能維持に大き く寄与するため維持管理上好ましいものといえる.

（2）堆積土砂流出の結果, 堰直下流で広く露出していた 土丹が砂礫で覆われ始めており, 砂碟河床を基本と する生態系の再生が期待される.
図-14 二次元河床変動計算結果（河床高変化）

（3）堰上流では，旧堰により堆積した土砂の流出および 固定砂州の侵食により河道断面が増大しつつあり, 治水上好ましい傾向にあるといえる。

以上のように，堰敷高の切下げを契機として土砂移 動が活発化することによって, これまでの不均衡が改 善され, 好ましい状況が現れ始めたといえる. 今後も 堰周辺の河床モニタリングを継続し, その検討結果を 河道の維持管理に反映させていきたい。

また, 二次元河床変動計算による河床変化予測の可 能性を調べるため, ここで得られた河床変化を対象と して再現計算を行った. 計算結果は, 堰周辺の洗掘, 堆積の傾向を概ね表しており, 河床変化予測が可能で あることがわかった. 今後は計算モデルの精度向上を 図り，他の事例に適用していきたい。

\section{参考文献}

1）(財)国土開発技術研究センター: 平成5年度 多摩川河道計画 検討委員会 概要報告書, 1994.

2) 小川ら : 二次元河床変動解析の現地への適用に関する研究, 水工学論文集, 第43巻, pp. 701-706, 1999.

(2003. 9. 30受付) 